\title{
Predicar en la misericordia. Los viajes apostólicos del papa Francisco en América
}

\author{
Preachings on Mercy. Pope Francisco's Pastoral Visits to \\ America
}

\author{
Miguel J. Hernández Madrid \\ El Colegio de Michoacán \\ miguelh@colmich.edu.mx \\ DOI: I0.2490I/rehs.v40i157.334
}

\section{(c) (i) (8)}

Predicar en la misericordia. Los viajes apostólicos del papa Francisco en América. por Miguel Jesús Hernández Madrid se distribuye bajo una Licencia Creative Commons AtribuciónNoComercial 4.0 Internacional.

Fecha de recepción: 26 de julio de 2017

Fecha de aprobación: 3 de marzo de 2018

\section{RESUMEN:}

¿Por qué persuadir a la lectura de este artículo donde se analizan las predicaciones del papa Francisco sobre la misericordia en sus visitas apostólicas a países de Latinoamérica y en Estados Unidos? Por tres razones que dan cuerpo a nuestro argumento, empezando por la primicia de este valor de relación humana en el contexto contemporáneo y mundial de movimientos de conciencia, que convocan a restaurarlo en el centro de la moral y la religión. Segunda, por lo que de acontecimiento tiene Francisco al instaurar la misericordia como pilar de renovación de una Iglesia misionera. Tercera, porque la predicación papal en la misericordia revela una semántica construida en la experiencia pastoral de la Iglesia latinoamericana para enfrentar retos de un cambio de época, interpretados como signos de los tiempos: exclusión, incertidumbre, miedo. Las fuentes principales de los datos procesados son los documentos oficiales de la Santa Sede sobre las intervenciones de Francisco en Brasil, Estados Unidos y México durante sus visitas apostólicas realizadas entre 2013 y 2016.

Palabras clave:

Papa Francisco, misericordia, Iglesia continental, discípulos, misioneros. 


\section{ABSTRACT:}

Why should readers be persuaded to peruse this analysis of Pope Francisco's preachings on mercy delivered during his pastoral visits to the United States and nations in Latin America? The argument presented herein suggests three reasons, beginning with the primacy of the value of human relationships in the contemporary, worldwide context of movements of consciousness and their calls to restore mercy to the center of morality and religion. The second has to do with the importance that Francisco attributes to mercy by establishing it as one of the pillars of a renewed missionary Church; while the third sustains that papal preachings on mercy reveal a semantics constructed upon the pastoral experience of the Latin American Church as it confronts emerging challenges in this this epoch of change -exclusion, uncertainty and fearwhich are interpreted as signs of our time. The main data sources analyzed are official documents issued by the Holy See in relation to Pope Francisco's pastoral visits to Brazil, the United States and Mexico between 2013 and 2016.

Keywords:

Pope Francisco, mercy, continental Church, disciples, missionaries.

\section{Introducción}

Lampedusa es una pequeña isla en la frontera marítima mediterránea de Italia con los países del nordeste de África. A sus playas llegan con frecuencia los sobrevivientes de naufragios y los cadáveres de niños, hombres y mujeres ahogados; personas expulsadas de sus países por las guerras, las hambrunas, el desempleo, intentando cruzar el océano en balsas y embarcaciones destartaladas para buscar un mejor modo de vida en Europa.

El primer viaje apostólico del papa Francisco fue aquí el 8 de julio de 20i3, a pocos días de haber ocurrido uno de los naufragios más desastrosos del año. En la homilía de la misa que ofició dijo: "sentí que tenía que venir hoy a rezar, a realizar un gesto de cercanía, pero también a despertar nuestras conciencias para que lo que ha sucedido no se repita". I Casi un mes después, Francisco declaró en una entrevista que veía a la Iglesia como un "hospital en campaña tras una batalla":

Yo sueño con una Iglesia Madre y Pastora. Los ministros de la Iglesia tienen que ser misericordiosos, hacerse cargo de las personas, acompañándolos como el buen samaritano que lava, limpia y consuela a su prójimo. Esto es Evangelio puro. Dios es más grande que el pecado. Las reformas organizativas y estructurales son secundarias, es decir, vienen después. ${ }^{2}$

Han transcurrido cinco años de la elección del primer papa latinoamericano y jesuita, tiempo suficiente para apreciar su compromiso cabal con el proyecto de una Iglesia renovada en la misericordia y lo que esto implica en su calidad teológica de signo e instrumento para implementar el Reino de Dios anunciado por Cristo en los Evangelios. ${ }^{3}$ Colocar la misericordia en el centro del sentido pastoral y moral de la Iglesia es una acción equiparable a lo que convocan e impulsan otros movimientos de conciencia ecuménica en varias partes del mundo que, como 
en el caso de la organización Charter for Compassion coordinada por la historiadora Karen Armstrong, ${ }^{4}$ proponen restaurar la compasión en la ética y la religión de una manera tal que fomente prácticas de empatía con el sufrimiento de los seres humanos y la garantía de proporcionar a los jóvenes información veraz y respetuosa sobre otras tradiciones y culturas.

Después de que los estudios sociológicos sobre la religión en Occidente desplazaron el debate del problema de su supervivencia en el mundo moderno al reconocimiento de su rearticulación para ampliar sus códigos de comunicación de la fe en sociedades secularizadas, volvemos a recuperar las cuestiones planteadas por Max Weber sobre el papel de la religión y de las tradiciones espirituales en la evolución histórica de la especie humana. En el marco de los movimientos de conciencia mencionados y de la pastoral del papa Francisco nos preguntamos, siguiendo a Weber, ${ }^{5}$ ¿cuál es la influencia de la Iglesia sobre el universo social del ethos caracterizado por motivos específicamente religiosos?

En este artículo se aportan algunas reflexiones sobre dicha cuestión general al enfocar el análisis en las predicaciones de Francisco durante sus visitas apostólicas en el continente americano, entre 2013 у 2016.

Nuestro argumento propone que la Iglesia de la misericordia impulsada por Francisco es la expresión pastoral de una renovación eclesiológica dirigida a recuperar su vocación discipular y misionera, para responder a los desafíos del cambio de época que la Iglesia discierne en su lectura de los signos de los tiempos. La Iglesia de la misericordia tiene en Latinoamérica y el Caribe una connotación misionera continental, apoyada en la V CELAM de Aparecida, Brasil, $\frac{6}{y}$ en las experiencias pastorales de las Iglesias particulares derivadas de ella.

La perspectiva sociológica en la que nos apoyamos para comprender y aprender sobre la Iglesia en la misericordia retoma de la fenomenología su lectura epistemológica de la realidad empírica sin la mediación a priori de un aparato conceptual. Un puente clave de la sociología fenomenológica en su lectura de la realidad social es la atención al lenguaje, por su capital importancia para significar la subjetividad humana en procesos de comunicación e interacción. ${ }^{7} \mathrm{Al}$ elegir la predicación del papa como fuente de saber se reivindica esta característica del lenguaje que, en los contextos de interacción social y religiosa donde se pronuncia, permite rebasar su tratamiento como sermón retórico y postularla como un acontecimiento de acción comunicativa.

Para que haya una acción comunicativa, en los términos postulados por Habermas, es necesario explorar en la predicación del papa si

las convicciones compartidas intersubjetivamente vinculan a los participantes en forma de reciprocidad; el potencial de razones asociado a las convicciones constituye entonces una base aceptada, en la que uno puede estribar para apelar al buen sentido del otro. $\underline{\underline{8}}$ 
Francisco ha insistido en una pedagogía pastoral de la predicación que no se confunda con un espectáculo, en la lógica de las tecnologías mediáticas, y que cumpla su misión de encuentro con la grey. ${ }^{2}$ Desde un punto de vista metodológico se ha tomado la palabra al papa para observar en sus visitas apostólicas la articulación entre la estructura de sus predicaciones, sus maneras de interacción con las personas que lo escuchan y dialogan, así como las recuperaciones cercanas que él hace de las breves experiencias de encuentro, para compartirlas y reflexionarlas en el curso de sus visitas. Se ha cuidado no limitar la construcción de los datos en el dominio del análisis del discurso; no obstante, las aportaciones de los precursores de la "aventura semiológica", como

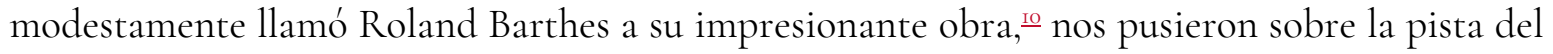
análisis estructural del relato para identificar las características de los significados que cobran vida como ideas fuerza en torno al gran significante que constituyen los Evangelios. Francisco predica con base en su discernimiento de los "signos de los tiempos", esto es "de la manifestación de los valores evangélicos actuando en el interior de la sociedad humana en el rumbo de la historia".II En el actuar de la fe, el discernimiento de los "signos de los tiempos" es reconocer las llamadas que el Señor dirige a su pueblo desde el fondo de las realidades profanas colectivas, interpelándolo continuamente.

Interpelar es el verbo activo en una oración breve: el papa interpela con su predicación a la grey, porque juega con el significado gramatical de predicado y el pastoral de predicación. Por esta sola intención cada frase y oración de la predicación tiene un argumento en su confección y urdimbre a lo largo del discurso..$^{-2}$ Cabe aclarar que en el contexto de la acción comunicativa propuesta como hipótesis de trabajo, la interpelación referida es muy diferente a la definida en el enfoque de Althusser para analizar la ideología. Una diferencia básica es que en el análisis de la ideología, la interpelación rastrea la constitución de un sujeto simbólico reducido a "lo real", ${ }_{4}$ mientras que en la de la acción comunicativa pastoral el individuo es tratado con toda la riqueza de su personalidad en un punto singular de subjetividad como discípulo de Cristo.

Los viajes apostólicos del papa son un escenario ideal para observar los contenidos e interacciones aludidos. Por iniciativa de la Santa Sede, el viaje apostólico es una variante de la visita canónica orientado por su objetivo pastoral; corresponde al papa realizarlo en su calidad de obispo de Roma a las diócesis bajo su responsabilidad en todo el mundo. ${ }^{15}$ El acento no se pone en la inspección tradicional de la visita canónica, sino en el acompañamiento pastoral y misionero con los apóstoles de Cristo en la Iglesia. Francisco ha dejado en claro este objetivo, como lo hizo en su arribo a México (2016), al decir: "Hoy vengo como misionero de misericordia y paz pero también como hijo que quiere rendir homenaje a su madre, la Virgen de Guadalupe, y dejarse mirar por ella” $\underline{\underline{6}}$.

Para estudiar, cómo predicó Francisco, la Iglesia de la misericordia durante sus visitas apostólicas se eligieron las realizadas en el continente americano porque, en primer lugar, la primera de ellas fuera de Italia la realizó en Río de Janeiro, Brasil, para celebrar la XXVIII Jornada Mundial de la Juventud y por el peso pastoral que tiene el santuario de Aparecida, donde se podría afirmar que nació el proyecto de renovación de la Iglesia continental con la V CELAM en 2007. Además de Brasil, entre 2013 y 2016, Francisco visitó Estados Unidos, donde tuvo dos intervenciones trascendentes, una en el Congreso y la otra en la Organización de las Naciones 
Unidas; también viajó en dos ocasiones a Cuba y en tres de los países latinoamericanos más pobres: Bolivia, Ecuador y Paraguay. Finalmente, en 2016 visitó México donde el santuario de la Virgen de Guadalupe fue reivindicado en su magnitud pastoral de Iglesia madre para todo el continente, como lo hizo en Aparecida.

Las fuentes de datos de este artículo están en orden de importancia: a) los discursos de Francisco registrados oficialmente por la Librería del Vaticano en sus intervenciones públicas (de los cuales se consultaron 75 documentos); b) el seguimiento de las visitas por medios de información multimedia; c) artículos de prensa pública y de medios católicos; d) documentos del magisterio eclesiástico a los que remiten las citas y referencias de Francisco en sus intervenciones; e) bibliografía especializada sobre el papa Francisco y la biográfica de Mario Jorge Bergoglio SJ.

La Iglesia de la misericordia en clave misionera

La cruz pectoral que porta Francisco es la misma que traía cuando fue cardenal de la provincia de Buenos Aires. Desde un punto de vista iconográfico es la representación de un pastor con sus ovejas, llevando sobre los hombros a una de ellas y en la cúspide de la cruz una paloma simbolizando el Espíritu Santo. Cualquiera que sea el motivo personal del padre Bergoglio para portarla, lo destacable es el significante novedoso de la imagen del pastor a diferencia de las estilizaciones del Cristo clavado en los crucifijos pontificales de todos los papas anteriores. Si la salud de la religión depende, como escribió Mardones, de la vitalidad con que se asuman los símbolos religiosos, ${ }^{17}$ entonces la representación pastoral forjada en la cruz de Francisco anuncia el sentido de renovación de la Iglesia misionera que él predica.

Tres parábolas del Evangelio que Francisco trabajó como referentes constantes en sus predicaciones y encuentros durante los viajes apostólicos son la del Buen Samaritano (Lc IO, 2937), la del Pastor que halla a su oveja perdida (Lc i5, 3-7) y la del encuentro en Emaús (Lc 24, I3I5). La función de la parábola en los Evangelios trasciende su eficacia literaria y tiene mayor contenido que la alegoría, en la medida que es la manera adecuada de comunicar a una escucha

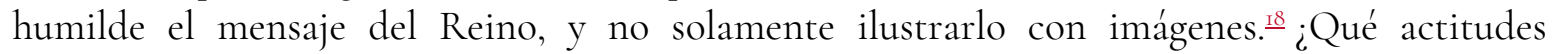
atraviesan el relato de estas parábolas?: la misericordia de un hombre que se compadece de otro cuando lo halla herido en el camino después de haber sido asaltado y no lo trata como el enemigo que en su cultura lo designa como tal, sino como su prójimo; el cuidado responsable de un pastor por sus ovejas, cuando una de ellas se pierde y sale a buscarla aunque tenga aseguradas las restantes noventa y nueve; el encuentro en un atardecer de dos discípulos de Jesús que huyendo de Jerusalén se unen a un peregrino (Jesús resucitado) y no lo reconocen, pero le ofrecen hospitalidad para guarecerse de la noche. Al tenor de las tres parábolas, la misión de una Iglesia que se pronuncia como un "hospital en campaña" se debe a que los pastores tienen que salir de los templos para encontrarse con su grey, y los discípulos a predicar el Evangelio en su solidaridad y apoyo a sus hermanos desvalidos:

Releamos una vez más el episodio de Emaús. Es el misterio difícil de quien abandona la Iglesia, de aquellos que, tras haberse dejado seducir por otras propuestas, creen que la Iglesia -su Jerusalén- ya no puede ofrecer algo significativo e importante. Y, 
entonces, van solos por el camino con su propia desilusión. Tal vez la Iglesia se ha mostrado demasiado débil, demasiado lejana de sus necesidades, demasiado pobre para responder a sus inquietudes, demasiado fría para con ellos, demasiado autorreferencial, prisionera de su propio lenguaje rígido; tal vez el mundo parece haber convertido a la Iglesia en una reliquia del pasado, insuficiente para las nuevas cuestiones; quizás la Iglesia tenía respuestas para la infancia del hombre, pero no para su edad adulta. ${ }^{19}$

La cita anterior es una de las pocas intervenciones del papa en las que hizo referencia, con el adverbio "tal vez", a la posibilidad de que en el interior de la Iglesia haya causas de su crisis. Cuidadosa prudencia de Francisco en exponer públicamente los problemas de fondo de la Iglesia, a excepción de su intervención con el episcopado mexicano, a quienes hizo señalamientos y exhortaciones fuertes sobre la necesidad de la comunión y unidad interna por encima de las diferencias entre ellos. 20

Consistente con la "mirada sobre la realidad" que los obispos de la V CELAM exponen en el documento de Aparecida, Francisco refirió continuamente que los problemas del cambio de época, causantes de un extremo sufrimiento en las personas y la naturaleza, remiten a una economía global fomentadora de una cultura del consumo egoísta para fortalecer la riqueza entre minorías privilegiadas; en la exclusión y descarte de dos generaciones vitales para la renovación de la sociedad: los jóvenes como garantes del futuro y los viejos como portadores de la sabiduría y memoria; el relativismo que permea toda multi y pluridiversidad, al punto de no contar con una visión unitaria que permita ejercer la libertad con discernimiento y responsabilidad; las interrupciones para transmitir de una generación a otra, con la misma fluidez que antes, los valores, sabidurías y tradiciones culturales que sostenían los tejidos sociales y dignificaban el trabajo.

En este complejo panorama problemático del cambio de época, Francisco retoma en su predicación la escucha y lectura de los signos de los tiempos, ya denunciados en Lampedusa, como el sufrimiento humano infligido en los contextos de economías voraces por las riquezas, la exclusión y el tráfico de muerte (refiriéndose al narcotráfico), relacionados con el fomento de una cultura de la indiferencia ante el dolor de los demás. Al afirmar que la misericordia es la respuesta pastoral de la Iglesia a estos llamados, Francisco se refiere a ella en los siguientes términos:

Quisiera recordar que "pastoral" no es otra cosa que el ejercicio de maternidad de la Iglesia. La Iglesia da a luz, amamanta, hace crecer, corrige, alimenta, lleva de la mano [...] Se requiere, pues, una Iglesia capaz de redescubrir las entrañas maternas de la misericordia. Sin la misericordia, poco se puede hacer hoy para insertarse en un mundo de "heridos", que necesiten comprensión, perdón, amor.픈

La literatura tipo best seller que se ha escrito sobre el papa tiende a construirlo como un personaje con un carisma excepcional destinado a realizar reformas profundas en la Iglesia, enfrentando fuerzas de oposición poderosas y conservadoras, como las de la Curia Romana. $\stackrel{22}{=}$ Sin demeritar 
los hechos de las relaciones de poder en el campo religioso donde la Iglesia católica es uno de los agentes principales, como tampoco el reconocido carisma de Francisco, ${ }^{23}$ consideramos que este enfoque centrado en el personaje no ubica en la perspectiva correcta lo que representa la Iglesia de la misericordia, en un proceso histórico de su transformación en el tiempo de larga duración que acontece en el siglo XX y lo que va del XXI. A continuación se proponen tres coordenadas para dar seguimiento a las rutas críticas que abrevan en el "momento actual" de la Iglesia de la misericordia, según el decir de Francisco.

Se ha vuelto un lugar común la expresión de que la Iglesia se mueve a su propio paso, pero no en sintonía con la velocidad vertiginosa del mundo moderno, ni con el de las necesidades y expectativas de los creyentes católicos que esperan de ella cambios claros y precisos de lo que tanto se dice en su retórica doctrinaria. Lo cierto es que una coordenada de corte teológico y eclesiológico imprescindible para comprender a la Iglesia en su movimiento es la articulación pertinente entre Reino-Mundo-Iglesia.

Siguiendo a Leonardo Boff en su explicación teológica al respecto escribe "la Iglesia no puede entenderse en sí y por sí misma, porque está al servicio de unas realidades que la trascienden: el Reino y el mundo". ${ }^{24}$ El Reino, continúa exponiendo Boff, es una categoría empleada por Jesús, tal como la relatan los Evangelios sinópticos, ${ }^{25}$ que expresa la realización en el mundo del fin bueno de la totalidad de la creación de Dios, liberada de toda imperfección y penetrada por lo divino. El Reino consuma la salvación en su estado último.

El mundo es el lugar de la realización histórica del Reino, pero esto no ocurre porque el mundo está en decadencia corrompido por el pecado. De ahí que sea necesario el dispendioso proceso de liberación para que el mundo pueda acoger en sí al Reino. ${ }^{26}$ La Iglesia, continúa Boff,

es aquella parte del mundo que, en la fuerza del Espíritu, ha acogido al Reino de manera explícita en la persona de Jesucristo, el Hijo de Dios encarnado en nuestra opresión. La Iglesia no es el Reino, sino su signo (concreción explícita) e instrumento (mediación) de implementación en el mundo. ${ }^{27}$

Este marco teórico general ayuda a ubicar los diferentes modelos eclesiológicos que históricamente han orientado la articulación entre las tres dimensiones identificadas. ¿Qué permite a la Iglesia discernir lo correcto para realizar esta articulación? Su atenta lectura de los signos de los tiempos, tal como la hacen y comparten las Iglesias particulares en sus escalas territoriales y culturales. ${ }^{28}$ Ubicamos aquí otra coordenada, de carácter histórico.

La Iglesia del siglo XX aprendió a discernir los signos de los tiempos en las terribles guerras y sufrimientos por ellas provocadas, para volcarse hacia el mundo y escuchar desde los oprimidos, víctimas, desplazados y sin hogar lo que en su lectura del Evangelio Dios pedía a la Iglesia. En estos términos, palabras más o menos, se puede leer en varios documentos del magisterio social de la Iglesia durante la primera mitad del siglo XX que la misericordia inspiró acciones sociales inéditas al formar sacerdotes y laicos militantes, hombres y mujeres, jóvenes y veteranos de las 
guerras para trabajar con campesinos, obreros, mineros, inmigrantes, huérfanos, viudas, gente $\sin$ hogar. 29

El Concilio Vaticano II es, en este sentido, el gran acontecimiento de la Iglesia en el siglo XX, porque en él convergieron las experiencias pastorales construidas desde muchas bases parroquiales y familiares, posibilitando la creación del lenguaje teológico y magisterial con el que la Iglesia definió su papel en el mundo contemporáneo para responder a una época de cambios. Conviene precisar en este ámbito el significado de "experiencia", definida por Francisco, como "la realidad que encuentra eco en esa expresión que nace de la sabiduría". a Cabe comentar que en Buenos Aires, el joven Jorge Mario Bergoglio se formó en este ambiente familiar y parroquial de acción social católica, y ya como novicio y luego sacerdote jesuita mantuvo una retroalimentación pastoral constante en su contacto con las parroquias de las villas miseria, los marginados e inmigrantes..$^{3 I}$

Los documentos conciliares del Vaticano II son el referente obligado para reconocer la puesta al día de la Iglesia en el mundo moderno (aggiornamento) y el soporte macro, junto con algunas encíclicas con proyección social, ${ }^{32}$ que generaron en el continente americano las teologías latinoamericanistas, entre las que destacan las teologías de liberación en sus diversas corrientes y experiencias. A casi medio siglo de esa etapa histórica de la Iglesia latinoamericana se reflexiona con una distancia crítica la complejidad del fenómeno, incluso por varios de sus protagonistas que todavía viven. Esto ha contribuido a elaborar "cartografías" de experiencias colectivas en entornos eclesiásticos particulares y nacionales, comprensión de sus propuestas teológicas en el contexto de sus praxis, y rutas críticas seguidas por algunos movimientos que están presentes en los escenarios contemporáneos. Uno de estos movimientos es el que comparte el proyecto de una Iglesia renovada en la misericordia.

La tercera coordenada que traza el itinerario del proyecto de la Iglesia misional continental convoca la ruta de varias experiencias eclesiásticas caracterizadas por el trabajo episcopal colegiado y su pastoral de opción preferencial por los pobres. Ivereigh en su biografía del padre Bergoglio aporta datos sobre la influencia que tuvieron en él, desde sus años de formación y luego como profesor y provincial de la Compañía de Jesús en Buenos Aires, el pensamiento teológico de Romano Guardini e Yves Congar, que abordan el tema de la secularidad cristiana y de la necesidad de vincularlo con una teología de la creación y redención en las realidades terrestres; y de manera inmediata, en su terruño, del argentino Lucio Gera con la teología del pueblo. Gera recapitula las aportaciones de esta teología argentina en los siguientes términos:

Uno es la inclinación a asociar la reflexión teológica con la pastoral, esto es, pensamiento con la acción, con la praxis [...], lo cual lleva a la teología a plantearse un mayor conocimiento de la realidad histórica, de la situación en la que se desea resolver la reflexión teológica. [El otro es] la inclinación del pensamiento teológico a resolverse en la realidad fáctica concreta [...]. Esto hizo que la pobreza -no sólo el tema acerca de la pobreza de la Iglesia, sino el de los "pobres" del mundo- se sitiara en el centro de la reflexión teológica y hacia el horizonte en el que iban encaminados todos los tratamientos temáticos particulares. ${ }^{33}$ 
Al erigirse la praxis como derrotero pastoral que entreteje pensamiento, acción y reflexión, la misericordia como respuesta a los signos de los tiempos en un proyecto de Iglesia misional continental es un momento en su historia, relacionado con el sostenido esfuerzo del trabajo colegial de las comunidades eclesiales particulares que tuvieron su expresión más alta en la $\mathrm{V}$ CELAM de Aparecida, Brasil. En este contexto Susana Nuin, directora ejecutiva de comunicación del CELAM, afirma que el cardenal Bergoglio tuvo un rol fundamental en la confección del documento final de Aparecida. "Él fue permanentemente piloteando esta tarea que sus hermanos en episcopado le habían confiado", en su estilo metodológico de diálogo fue recibiendo todos los aportes de la Asamblea junto a la comisión con la que trabajaba, de tal forma que "hizo que todas la voces de la Asamblea entraran armónicamente y fueran más que un texto, una realidad". ${ }^{34}$

Cuando el is de febrero de 2013, Benedicto XVI anunció su renuncia, Ivereigh relata que el cardenal Bergoglio tendía a preparar su jubilación y ante la emergencia del evento asistió al Conclave en el Vaticano de donde salió nombrado papa. El teólogo de la liberación argentino Arturo Paoli, a quien Francisco recibió afectuosamente unas semanas antes de su fallecimiento, escribió que cuando la libertad se expresa como vocación significa la existencia por la real aceptación de sí mismo en las propias y determinadas circunstancias que se viven. De esta manera, la vocación como obediencia tiene la fuerza de hacernos salir de nosotros mismos y de apoderarse la ciudadela de la muerte que hay en nosotros. ${ }^{35}$

Al aceptar Bergoglio la responsabilidad como obispo de Roma es notable la recuperación de su vocación discipular y misional, sobre la cual alude constantemente la experiencia de la V CELAM en Aparecida, no solamente como el hecho histórico que es, sino como el punto de partida en un itinerario que compromete la renovación paradigmática de la Iglesia. Siguiendo a Francisco en su encuentro con el Comité de Coordinación del CELAM en Río de Janeiro, el cambio paradigmático "implica poner en clave misionera la actividad habitual de las Iglesias particulares"; de ahí que uno de los grandes desafíos para llevarlo a cabo sea

fomentar en todos los fieles el sentido de responsabilidad personal en la misión de la Iglesia y capacitarlos para que puedan cumplir con tal responsabilidad como discípulos misioneros como fermento del Evangelio en nuestro mundo. Esto requiere creatividad para adaptarse a los cambios de las situaciones, transmitiendo el legado del pasado, no sólo a través del mantenimiento de estructuras e instituciones, que son útiles, sino sobre todo abriéndose a las posibilidades que el Espíritu nos descubre y mediante la comunicación de la alegría del Evangelio, todos los días y en todas las etapas de nuestra vida. ${ }^{6}$

Interpelar en la misericordia

Francisco reivindica la importancia de la ternura para la cercanía y el encuentro misional, haciendo referencia a la dimensión materna de la Iglesia, presente en la devoción Mariana, cualquiera que sea su advocación cultural y religiosa. Es interesante rastrear en la etimología de la palabra misericordia, como lo hace Corominas, el significado latino que aparece ya en rzzo 
referido a quien "está formado con corazón", ${ }^{77}$ y las palabras asociadas misión-misionero como el portador de esa virtud. En Europa fue la época del poverello, San Francisco de Asís, de quien el papa ha tomado su nombre porque "para mí es el hombre de la pobreza, el hombre de la paz, el hombre que ama y custodia la creación”..$^{8}$ Con esta actitud de ternura, aunada a la de vigor, en sus interlocuciones con el pueblo fiel durante las visitas apostólicas identificamos algunos códigos que expresan significaciones de la misericordia.

Siguiendo a Barthes, 39 la función de estos códigos en la estructura del relato consiste en articular las ideas o mensajes que le imprimen fuerza y sentido. Las predicaciones de Francisco, según se ha señalado en el inicio de este artículo, tienen una clara intención pedagógica dirigida a exponer de manera sencilla y directa tres temas, casi siempre, que a la luz de la selección pertinente de un pasaje del Evangelio convoca a la reflexión.

En el cuadro i se presentan algunos de estos códigos; son muestras de maneras de decir las significaciones pastorales de la misericordia a quienes la palabra puede "tocar el corazón", porque se sabe que en "esos corazones" hay experiencias que comprenden y se enlazan con los mensajes. La limitación de este cuadro para "evidenciar" como dato lo anterior es que no permite articular todo el proceso de interacción entre Francisco con las personas, grupos y grandes colectivos en las circunstancias donde ocurrieron estos encuentros.

\begin{tabular}{|c|c|}
\hline Pueblo fiel & Códigos interpelativos de misericordia \\
\hline Pueblo & $\begin{array}{l}\text { Se accede a él por el portal de su corazón. } .^{40} \\
\text { La amorosa providencia de Dios (el gobierno divino) permite al } \\
\text { papa su acceso a las naciones en donde el Pueblo lo recibe con } \\
\text { sentimientos de amor y amistad. }{ }^{ \pm 1} \\
\text { Entre la indiferencia egoísta y la protesta violenta, siempre hay una } \\
\text { opción posible: el diálogo. [...] porque todos somos pueblo con la } \\
\text { capacidad de dar y recibir, permaneciendo abiertos a la verdad. }{ }^{42} \\
\text { La gente sencilla siempre tiene espacio para albergar el misterio. [...] } \\
\text { El misterio entra por el corazón. En la casa de los pobres, Dios } \\
\text { siempre encuentra sitio. }{ }^{43} \\
\text { Apelo aquí a la historia política de los Estados Unidos, donde la } \\
\text { democracia está radicada en la mente del Pueblo. Toda actividad } \\
\text { política debe servir y promover el bien de la persona humana, estar } \\
\text { fundada en el respeto de su dignidad.44 }\end{array}$ \\
\hline Jóvenes & La principal riqueza de México hoy tiene rostro joven. ${ }^{45}$ \\
\hline
\end{tabular}




\begin{tabular}{|c|c|}
\hline & 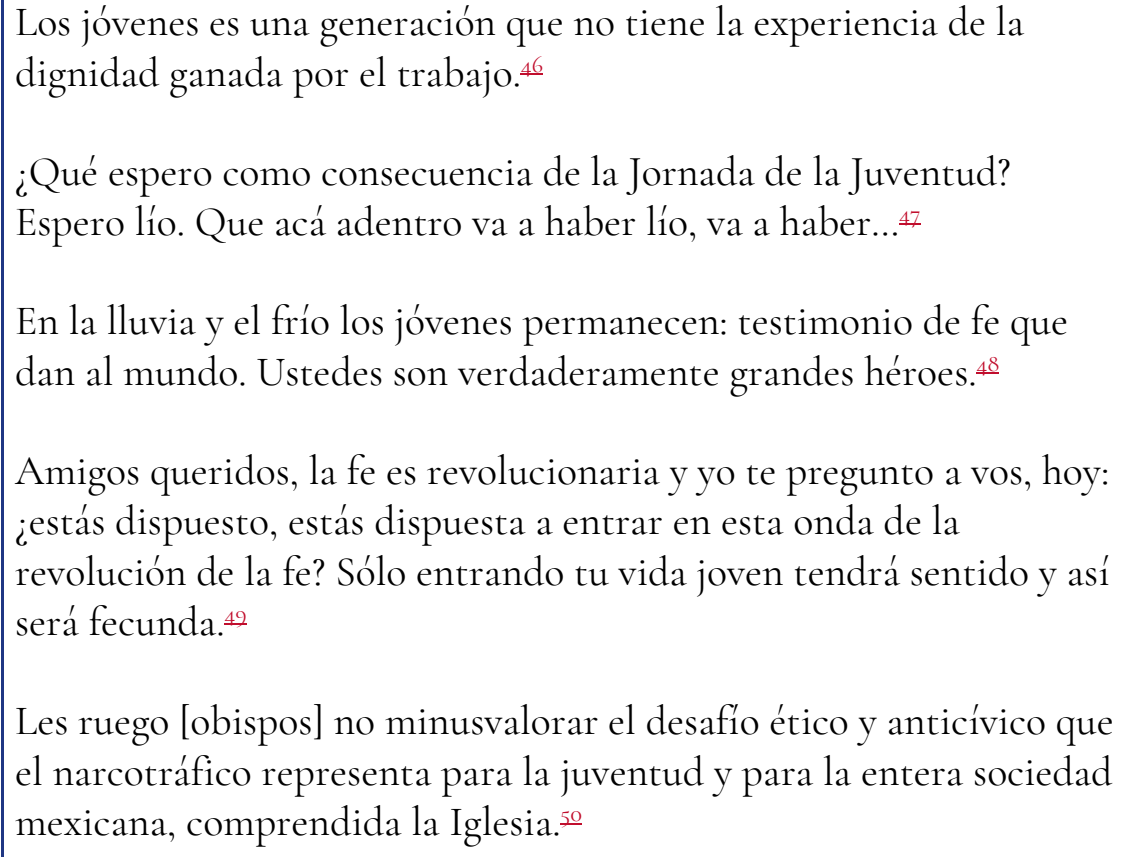 \\
\hline Familias & 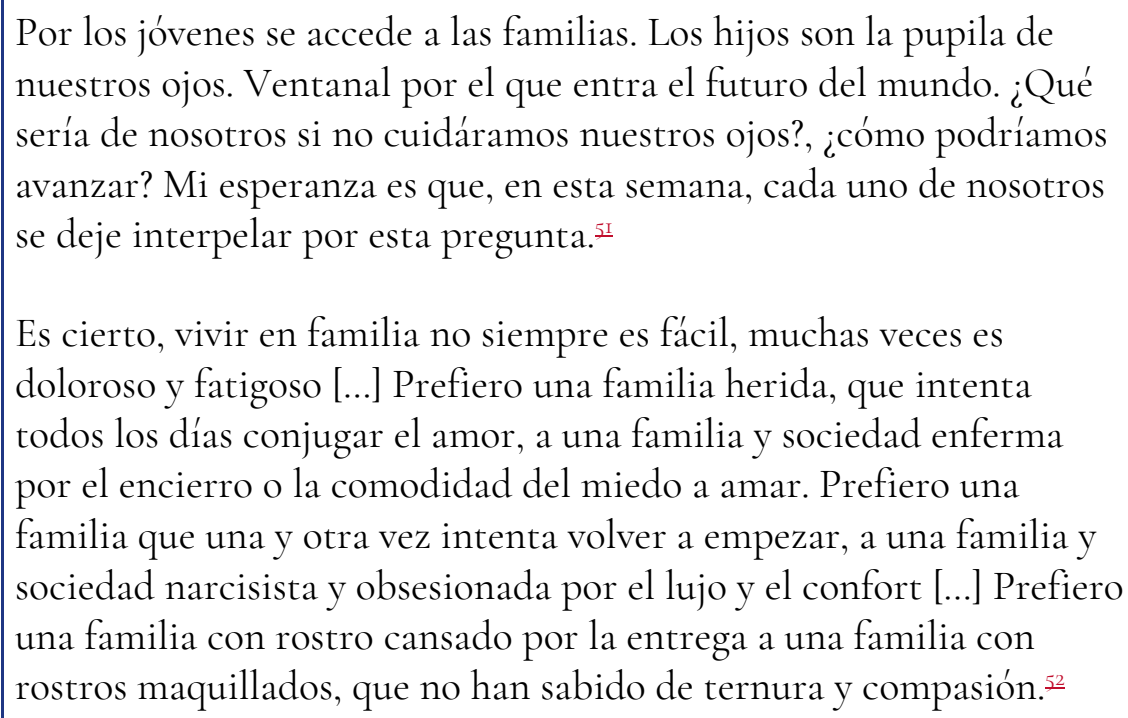 \\
\hline $\begin{array}{l}\text { Grupos en } \\
\text { condiciones de } \\
\text { readaptación social: a) } \\
\text { presos; y b) hospitales } \\
\text { contra dependencia } \\
\text { química }\end{array}$ & $\begin{array}{l}\text { Han conocido la fuerza del dolor y del pecado, no se olviden que } \\
\text { tienen al alcance la fuerza de la resurrección, la fuerza de la } \\
\text { misericordia que hace nuevas todas las cosas." } \\
\text { Recuerdo aquellas palabras de Jesús: "el que esté sin pecado que tire } \\
\text { la primera piedra", y yo me tendría que ir. Al decirles estas cosas no } \\
\text { lo hago como quien da cátedra, con el dedo en alto, lo hago desde la } \\
\text { experiencia de mis propias heridas, errores y pecados que el Señor } \\
\text { quiso perdonar y reeducar [...] Hermanos, siempre me pregunto al } \\
\text { entrar en una cárcel "ipor qué ellos y no yo?” Y es un misterio de la }\end{array}$ \\
\hline
\end{tabular}




\begin{tabular}{|c|c|}
\hline & $\begin{array}{l}\text { misericordia divina que ahora estamos celebrando todos mirando } \\
\text { hacia delante en esperanza. }{ }^{54} \\
\text { El hospital de rehabilitación es un santuario particular de } \\
\text { sufrimiento humano. Abrazo a cada una y cada uno de ustedes que } \\
\text { son la carne de Cristo. Pero abrazar no es suficiente, hay que } \\
\text { acompañar, tender la mano a quien con responsabilidad está } \\
\text { "subiendo", sabiendo que nadie puede subir por ti.55 } \\
\text { A los traficantes de la muerte que siguen la lógica del poder y el } \\
\text { dinero, no les dejaremos que nos roben la esperanza. }\end{array}$ \\
\hline Migrantes & $\begin{array}{l}\text { Nuestro mundo está afrontando una crisis de refugiados sin } \\
\text { precedentes desde los tiempos de la II Guerra Mundial. [...] A lo que } \\
\text { se suma, en este continente, las miles de personas que se ven } \\
\text { obligadas a viajar hacia el norte en búsqueda de una vida mejor para } \\
\text { sí y para sus seres queridos [...] ¿Acaso no es lo que nosotros } \\
\text { queremos para nuestros hijos? No debemos dejarnos intimidar por } \\
\text { los números, más bien mirar a las personas, sus rostros, escuchar sus } \\
\text { historias, mientras luchamos por asegurarles nuestra mejor respuesta } \\
\text { a su situación. }{ }^{57} \\
\text { Son millones los hijos de la Iglesia que hoy viven en la diáspora o en } \\
\text { tránsito, peregrinando hacia el norte en búsqueda de nuevas } \\
\text { oportunidades. [...] Hermanos [obispos] que sus corazones sean } \\
\text { capaces de seguirlos y alcanzarlos más allá de las fronteras. }{ }^{58} \\
\text { Refuercen la comunión con sus hermanos del episcopado } \\
\text { estadunidense, para que la presencia materna de la Iglesia mantenga } \\
\text { vivas las raíces de su fe.j9 } \\
\text { Entre nosotros hoy hay miembros de la gran población hispana de } \\
\text { los Estados Unidos, así como representantes de inmigrantes recién } \\
\text { llegados [...] Les pido que no olviden que, al igual que los que } \\
\text { llegaron aquí antes, ustedes traen muchos dones a esta nación. Por } \\
\text { favor, no se avergüencen nunca de sus tradiciones. No olviden las } \\
\text { lecciones que aprendieron de sus mayores y que pueden enriquecer } \\
\text { la vida de esta tierra americana. } .\end{array}$ \\
\hline $\begin{array}{l}\text { Comunidades } \\
\text { indígenas }\end{array}$ & $\begin{array}{l}\text { Los indígenas de México aún esperan que se les reconozca } \\
\text { efectivamente la riqueza de su contribución y la fecundidad de su } \\
\text { presencia para heredar aquella identidad que los convierte en una } \\
\text { Nación única y no solamente una entre otras. } \text {. }^{-}\end{array}$ \\
\hline
\end{tabular}




\begin{tabular}{|c|c|}
\hline & $\begin{array}{l}\text { Algunos han considerado inferiores sus valores, sus culturas y sus } \\
\text { tradiciones. Otros, mareados por el poder, el dinero y las leyes del } \\
\text { mercado, los han despojado de sus tierras o han realizado acciones } \\
\text { que las contaminaban. ¡Qué tristeza! Qué bien nos haría a todos } \\
\text { hacer un examen de conciencia y aprender a decir ¡Perdón!, iperdón, } \\
\text { hermanos! El mundo de hoy, despojado por la cultura del descarte, } \\
\text { los necesita. }{ }^{62}\end{array}$ \\
\hline $\begin{array}{l}\text { Excluidos: a) gente sin } \\
\text { hogar; y b) ancianos }\end{array}$ & $\begin{array}{l}\text { La exclusión económica y social es una negación total de la } \\
\text { fraternidad humana y un gravísimo atentado a los derechos } \\
\text { humanos y al ambiente. Los más pobres son los que más sufren estos } \\
\text { atentados por un triple grave motivo: son descartados por la } \\
\text { sociedad, son al mismo tiempo obligados a vivir del descarte y deben } \\
\text { injustamente sufrir las consecuencias del abuso del ambiente. }{ }^{63} \\
\text { Esta civilización mundial se pasó de rosca, porque es tal el culto que } \\
\text { ha hecho al dios dinero, que estamos presenciando una filosofía y } \\
\text { una praxis de exclusión de los dos polos de la vida que son las } \\
\text { promesas de los pueblos. Exclusión de los ancianos [...] y exclusión } \\
\text { de los jóvenes. }{ }^{64} \\
\text { Yo se los pido de corazón a los ancianos: no claudiquen de ser la } \\
\text { reserva cultural de nuestro pueblo que transmite la historia, la } \\
\text { justicia, la memoria. Abran la boca y enséñennos. }\end{array}$ \\
\hline $\begin{array}{l}\text { V'́ctimas de abuso } \\
\text { sexual }\end{array}$ & $\begin{array}{l}\text { Las palabras no pueden expresar plenamente mi dolor por el abuso } \\
\text { que han sufrido. Ustedes son preciosos hijos de Dios, que siempre } \\
\text { deberían esperar nuestra protección, nuestra atención y nuestro } \\
\text { amor. Estoy profundamente dolido porque su inocencia fue violada } \\
\text { por aquellos en quien confiaban [...] En todas las circunstancias, la } \\
\text { traición fue una terrible violación de la dignidad humana. } 6 \text { a } \\
\text { Llevo grabado en mi corazón las historias, el sufrimiento y el dolor } \\
\text { de los menores que fueron abusados sexualmente por sacerdotes. } \\
\text { Continúa abrumándome la vergüenza de que personas que tenían a } \\
\text { su cargo el tierno cuidado de esos pequeños los violaran y les } \\
\text { causaran grandes daños. Lo lamento profundamente. Dios llora. Los } \\
\text { crímenes y pecados de los abusos sexuales a menores no pueden ser } \\
\text { mantenidos en secreto por más tiempo, me comprometo a la celosa } \\
\text { vigilancia de la Iglesia para proteger a los menores y prometo que } \\
\text { todos los responsables rendirán cuenta. }\end{array}$ \\
\hline
\end{tabular}




\begin{tabular}{|l|l|}
\hline $\begin{array}{l}\text { inmenso valor para hacer brillar la luz de Cristo sobre el mal abuso } \\
\text { sexual de menores. } \frac{68}{6}\end{array}$ \\
$\begin{array}{l}\text { Para aquellos que fueron abusados por un miembro del clero, } \\
\text { lamento profundamente las veces en que ustedes o sus familias } \\
\text { denunciaron abusos, pero no fueron escuchados o creídos. Sepan } \\
\text { que el Santo Padre los escucha y les cree. Lamento profundamente } \\
\text { que algunos obispos no cumplieran con la responsabilidad de } \\
\text { proteger a los menores. Es muy inquietante saber que en algunos } \\
\text { casos incluso los obispos eran ellos mismos los abusadores. Me } \\
\text { comprometo a seguir el camino de la verdad, dondequiera que nos } \\
\text { pueda llevar. El clero y los obispos tendrán que rendir cuentas de sus } \\
\text { acciones cuando no protejan o abusen de los menores. } \frac{\text { ga }}{9}\end{array}$ \\
\hline
\end{tabular}

\section{Discusión}

El último viaje apostólico del papa Francisco a Chile en enero de 2018 mostró tensiones insoslayables entre la alta jerarquía eclesiástica con personas que integran el pueblo fiel. El problema, difundido en los medios de información impresa y mediática de Chile y otros países que cubrieron el evento, fueron las protestas públicas de varios feligreses pidiendo al papa la destitución del obispo Juan Barros, de la diócesis de Osorno, a quien acusan de complicidad y protección del exsacerdote Fernando Karadima, abusador de menores.

Las tensiones sociales remiten a noviembre de 2015 con el envío al Vaticano de una exhortación de la Primera Sala de la Corte Suprema de Chile solicitando acceder a todos los antecedentes de la investigación sobre el obispo Juan Barros Madrid por encubrimiento de abusos sexuales del expárroco Fernando Karadima. En un audio difundido el 2 de octubre de 2015 por la agencia Ahora Noticias, ${ }^{70}$ se ve y escucha al papa Francisco defender al obispo Barros:

Que piensen con la cabeza y no se dejen llevar de las narices por los zurdos que son los que armaron la cosa. Además la única acusación que hubo contra ese obispo fue desacreditada por la Corte Judicial. Si, por favor, no pierdan la serenidad Osorno sufre sí, por tonta. Porque no abre su corazón a lo que Dios dice y se deja llevar por las macanas que dice toda esa gente.

Casi dos años después, el viaje apostólico a Chile ocurre en un ambiente hostil para la Iglesia. Unos días antes del arribo del papa a Santiago tres templos católicos fueron incendiados en la provincia, se estima en diez el total de estos atentados al concluir su visita. Lo que no se había reportado en viajes anteriores ocurrió aquí: centenares de manifestantes descontentos por la visita, pancartas con lemas como "Ni zurdos ni tontos. Osorno sufre. Obispo Barros 
encubridor". 가 La expectativa de las organizaciones de laicos agredidos por Karadima para reunirse con el papa no fue considerada, aun cuando se reunió con otros grupos en privado para realizar el acto de petición de perdón y rezo ya tradicional en los viajes precedentes. La tensión subió de tono cuando al arribar a Iquique, Francisco reiteró su posición defensiva de Barros al comentar a una periodista: "El día que me traigan una prueba del obispo Barros, ahí voy a hablar. No hay una sola prueba en contra. Son calumnias". En respuesta las tres víctimas del exsacerdote Karadima que encabezan la demanda contra el obispo de Osorno respondieron a Francisco con la lectura de un documento que argumenta puntualmente sus demandas y referencias de evidencias, así como su protesta por la desacreditación que el papa hizo a sus denuncias al tildarlas de calumnias. ${ }^{72}$

Durante el viaje de regreso de Perú a Roma, en la conferencia de prensa dos reporteros abordaron el tema del obispo Barros y las víctimas de pederastia. Juan Pablo Iglesias, del diario La Tercera, planteó lo siguiente: “¿Por qué cree más al testimonio del obispo Barros que al de las víctimas?, ¿no se traiciona un poco la confianza hacia esas víctimas que usted planteó en Chile?". Francisco dio una extensa disertación sobre la diferencia entre "pruebas" y "evidencias" para contextualizar las investigaciones que el Vaticano ha realizado sobre el obispo Barros, concluyendo que no hay evidencia alguna presentada por las víctimas para enjuiciarlo. Ante esta respuesta, Matilde Burgos de CNN Chile preguntó al papa: “¿Por qué para usted el testimonio de las víctimas no es una evidencia?, ¿por qué no les cree?, ¿a qué atribuye usted que se considere su visita a Chile como un fracaso de fieles y un fracaso de que la Iglesia queda más dividida?" A las dos preguntas iniciales Francisco respondió:

El testimonio de las víctimas siempre es una evidencia. Siempre. En el caso de Barros no las hay: no hay evidencias. [...] Y lo otro, de Chile, es un cuento chino. Yo de Chile me vine contento. Yo no esperaba tanta gente en la calle, y eso -no pagamos la entrada ¿eh? Esa gente no fue pagada ni llevada en colectivo-.73

Las reacciones emotivas de Francisco provocaron controversias en la opinión pública y desconcierto entre los feligreses, quienes comentaron que "el papa dice una cosa pero acaba haciendo otra distinta". Examinando el viaje apostólico de Chile en su calidad de acontecimiento que, siguiendo a Zizek, "no es algo que ocurre en el mundo sino un cambio del planteamiento a través del cual percibimos el mundo y nos relacionamos con él”, ${ }^{74}$ ¿qué giro se percibe con respecto a la predicación en la misericordia analizada en este artículo?

Empecemos por llamar la atención en la vulnerabilidad del sentido comunicativo de la predicación mantenida en los viajes apostólicos en Latinoamérica anteriores a Chile; para percibirla no es el indicador más certero la información mediática en imágenes y reportajes que tienden a fabricar realidades, ${ }^{75}$ sino el hecho de mostrarse lo que de poder patriarcal tiene el dispositivo pastoral de la Iglesia. En primera instancia, no necesariamente hay una contradicción entre lo que el papa dice y hace, proponemos enfocar esta cuestión más como una paradoja instalada en la identidad imaginada por la alegoría del "pastor" con sus "ovejas", de la Iglesia "madre" con sus "hijos". Las situaciones críticas acontecidas en Chile descubren una relación equívoca entre el "pastor" empeñado en seguir viendo patriarcalmente a las "ovejas" (la feligresía) 
como menores de edad, solícitos de rescate, consuelo; pero, ¿por qué cuando esa "oveja" adulta ya no se refugia en su victimización, sino replica, "hace lío", denuncia al "pastor" como responsable de abuso escudado en su poder ministerial, reclamando justicia, entonces la reacción del "padre" se vuelca a la institucionalidad clerical para responder con el mensaje legal de la norma, en ese juego positivista de la prueba y evidencia?, ¿qué pasó con la escucha al otro?, ¿por qué a los heridos en campaña que no siguen mansamente la interpelación del perdón y consuelo del papa necesariamente son descalificados ideológicamente?, ¿dónde se perdió la coherencia de encuentro postulada en el discurso pastoral renovador de la misericordia?

\section{Consideraciones finales}

La Iglesia de la misericordia en su calidad de renovación eclesiológica es una propuesta que trasciende la dimensión sistémica de la institución, al destacarse como "corazón" ético y moral de la conducta humana en el mundo del siglo XXI, donde hay otros movimientos de conciencia que reivindican estos valores. La Iglesia que impulsa Francisco tiene la intención de enfocar en el hacer de la fe un encuentro misericordioso con los seres humanos y la naturaleza, para entender las alternativas históricas que ofrece el presente. Es una búsqueda ecuménica y plural que, a la par, es necesario compartir con otras religiones y con todos aquellos seres de buena voluntad comprometidos con el cuidado de sí, de los otros y del medio donde habitan.

Paradójicamente, los principales obstáculos que enfrenta el proyecto de una Iglesia renovada provienen de la misma institución, y no competen solamente a los de su dimensión política y sociorreligiosa, al del liderazgo mundial del papa como jefe de Estado y de la Iglesia católica, como bien lo han analizado en su complejidad varios especialistas ya citados. Benedicto XVI y Francisco reconocen también la presencia de un dilema expresable en términos teológicos y eclesiológicos como la aceptación de que el bien y el mal conviven internamente en la conformación histórica de la Iglesia, y no como una dicotomía donde el mal es una fuerza externa y ajena. Giorgio Agamben ${ }^{6}$ al analizar la trascendencia histórica y ética de la renuncia de Benedicto XVI pone en perspectiva el dilema anterior en el problema de la legalidad y la legitimidad; en la dialéctica bien/mal, la Iglesia tendió a hundirse en la esfera económica, en las causas inmediatas de los poderes de gobierno facultando el desarrollo normativo y legal de la institución, pero descuidando el de su legitimidad en su presencia espiritual a los signos de los tiempos. Benedicto XVI procuró fortalecer doctrinariamente a la Iglesia, y Francisco, ahora, a impulsar su vocación misionera llevando plenamente a la praxis las atoradas y saboteadas constituciones del Concilio Vaticano II. 77 En el marco de este escenario de fin de los tiempos y era mesiánica de la Iglesia, la Iglesia de la misericordia es la apuesta en la que un papa construido en la visión patriarcal y del poder pastoral institucional interpela a los católicos para que el Evangelio no sea una predicación desde su persona sino la palabra llevada a la acción colectiva. Por todo esto, la justicia que se exige para afrontar el crimen de la pederastia clerical es porque atenta directamente con la misericordia al abusar de las personas en su integridad física, emocional y espiritual, por traicionar la confianza moral e intelectual que da sentido a su fe. Francisco ha mostrado la fuerza que tiene la misericordia en las palabras del Evangelio, pero falta citar y llevar a la práctica legítima, y no sólo legal, unas que no tienen equívoco: "Y quien 
haga caer a uno de estos pequeños que creen en mí, mejor le sería que le fuera colocada alrededor del cuello una piedra de molino asnal y fuera arrojado al mar (Mc 9, 42)"..$^{8}$

\section{Agradecimientos}

Agradezco a la maestra Pilar Alvarado su apoyo profesional para compilar y editar en el programa CITAVI los documentos electrónicos de la Librería Editrice Vaticana, a la licenciada Mariana Hernández A. en la revisión de estilo, y a Paul Kersey J. por la traducción al inglés del resumen de este artículo. 
Citas

\section{Documentos electrónicos de la Librería Editrice Vaticana (LEV)}

Documento r. "Visita a Lampedusa. Homilía del Santo Padre Francisco. Campo de Deportes Arena. Lunes 8 de julio de 2013", Librería Editrice Vaticana. En http://w2.vatican.va/content/francesco/es/homilies/2orz/documents/papafrancesco_20r30708_omelia-lampedusa.html(Fecha de consulta: 20 de junio de 2017). Brasil 2013.

Documento 2. "Viaje apostólico del Papa Francisco a Río de Janeiro. Ceremonia de bienvenida. Jardines del Palacio Guanabara de Río de Janeiro. Jueves 22 de julio de 20I3", Librería Editrice Vaticana. En http://w2.vatican.va/content/francesco/es/speeches/20I3/july/documents/papafrancesco_20I30722_gmg-cerimonia-benvenuto-rio.html(Fecha de consulta: 26 de junio de 2017).

Documento 3. "Viaje apostólico del Papa Francisco a Río de Janeiro. Visita al Hospital San Francisco de Asís de la Providencia V.O.T. Miércoles 24 de julio de 2013", Librería Editrice Vaticana. En http://w2.vatican.va/content/francesco/es/speeches/20i3/july/documents/papafrancesco_20130724_gmg-ospedale-rio.html (Fecha de consulta: 26 de junio de 20I7).

Documento 4. "Viaje apostólico del Papa Francisco a Río de Janeiro. Visita a la comunidad de Varginha. Jueves 25 de julio de 2013", Librería Editrice Vaticana. En http://w2.vatican.va/content/francesco/es/speeches/20r/july/documents/papa-

francesco_20130725_gmg-comunita-varginha.html (Fecha de consulta: 26 de junio de 20I7).

Documento 5. "Viaje apostólico del Papa Francisco a Río de Janeiro. Encuentro con los jóvenes argentinos en la catedral de San Sebastián. Jueves 25 de julio de 20I3", Librería Editrice Vaticana. En http://w2.vatican.va/content/francesco/es/speeches/2orz/july/documents/papafrancesco_20r30725_gmg-argentini-rio.html (Fecha de consulta: 26 de junio de 2017).

Documento 6. "Viaje apostólico del Papa Francisco a Río de Janeiro. Fiesta de acogida de los jóvenes. Saludo y homilía del Santo Padre Francisco. Paseo marítimo de Copacabana. Jueves 25 de julio de 2013", Librería Editrice Vaticana. En http://w2.vatican.va/content/francesco/es/speeches/20I3/july/documents/papafrancesco_20130725_gmg-giovani-rio.html (Fecha de consulta: 26 de junio de 20I7).

Documento 7. "Viaje apostólico del Papa Francisco a Río de Janeiro. Encuentro con el Episcopado brasileño. Sábado 27 de julio de 2013", Librería Editrice Vaticana. En http://w2.vatican.va/content/francesco/es/speeches/20r3/july/documents/papafrancesco_20I30727_gmg-episcopato-brasile.html (Fecha de consulta: 26 de junio de 20I7). 
Documento 8. "Viaje apostólico del Papa Francisco a Río de Janeiro. Encuentro con la clase dirigente de Brasil. Teatro Municipal de Río de Janeiro. Sábado 27 de julio de 20r3”, Librería Editrice Vaticana.

En http://w2.vatican.va/content/francesco/es/speeches/20r3/july/documents/papafrancesco_20130727_gmg-classe-dirigente-rio.html (Fecha de consulta: 26 de junio de 2017).

Documento 9. "Viaje apostólico del Papa Francisco a Río de Janeiro. Encuentro con el Comité Coordinador del CELAM. Centro de Estudios de Sumaré. Domingo 28 de julio de 20r3", Librería Editrice Vaticana.

En http://w2.vatican.va/content/francesco/es/speeches/20i3/july/documents/papafrancesco_20I30728_gmg-celam-rio.html (Fecha de consulta: 26 de junio de 20I7).

Documento Io. "Viaje apostólico del Papa Francisco a Río de Janeiro. Santa Misa con los obispos del XXVIII JMJ y con los sacerdotes, religiosos y seminaristas. Sábado 27 de julio de 2013", Librería Editrice Vaticana. En http://w2.vatican.va/content/francesco/es/homilies/20iz/documents/papafrancesco_20130727_gmg-omelia-rio-clero.html (Fecha de consulta: 26 de junio de 20I7).

Documento ir. "Viaje apostólico del Papa Francisco a Río de Janeiro. Encuentro con el Comité Coordinador del CELAM. Centro de Estudios de Sumaré. Domingo 28 de julio de 20r3", Librería Editrice Vaticana. En http://w2.vatican.va/content/francesco/es/speeches/20I3/july/documents/papafrancesco_20130728_gmg-celam-rio.html (Fecha de consulta: 26 de junio de 2017). Estados Unidos 2015.

Documento r2. "Viaje apostólico del Papa Francisco a Cuba y Estados Unidos de América. Encuentro con los obispos de los Estados Unidos de América. Catedral de San Mateo Apóstol, Washington D.C. Miércoles 23 de septiembre de 2015", Librería Editrice Vaticana. En http://w2.vatican.va/content/francesco/es/speeches/2015/september/documents/papafrancesco_20150923_usa-vescovi.html (Fecha de consulta: 23 de junio de 20I7).

Documento I3. "Viaje apostólico del Papa Francisco a Cuba y Estados Unidos de América. Visita al Congreso de los Estados Unidos de América, Washington D.C. Jueves 24 de septiembre de 2015", Librería Editrice Vaticana. En http://w2.vatican.va/content/francesco/es/speeches/2015/september/documents/papafrancesco_20150924_usa-us-congress.html (Fecha de consulta: 23 de junio de 20I7).

Documento I4. "Viaje apostólico del Papa Francisco a Cuba y Estados Unidos de América. Visita a la sede de la Organización de las Naciones Unidas. New York. Viernes 25 de septiembre de 2015", Librería Editrice Vaticana. En http://w2.vatican.va/content/francesco/es/speeches/20I5/september/documents/papafrancesco_20150925_onu-visita.html (Fecha de consulta: 23 de junio de 2017).

Documento I5. "Viaje apostólico del Papa Francisco a Cuba y Estados Unidos de América. Santa Misa con obispos, sacerdotes y religiosos. Sábado 26 de septiembre de 2015", Librería 
Editrice

Vaticana.

En http://w2.vatican.va/content/francesco/es/homilies/2015/documents/papa-

francesco_20150926_usa-omelia-philadelphia.html (Fecha de consulta: 23 de junio de 2017).

Documento i6. "Viaje apostólico del Papa Francisco a Cuba y Estados Unidos de América. Encuentro para la libertad religiosa con la comunidad hispana y otros inmigrantes. Filadelfia. Sábado 26 de septiembre de 2015", Librería Editrice Vaticana. En http://w2.vatican.va/content/francesco/es/speeches/20I5/september/documents/papafrancesco_20150926_usa-liberta-religiosa.html (Fecha de consulta: 23 de junio de 2017).

Documento I7. "Viaje apostólico del Papa Francisco a Cuba y Estados Unidos de América. Encuentro con víctimas de abusos sexuales. Seminario de San Carlos Borromeo. Filadelfia. Domingo 27 de septiembre de 2015", Librería Editrice Vaticana. En http://w2.vatican.va/content/francesco/es/speeches/2015/september/documents/papafrancesco_20I50927_usa-vittime-abusi.html (Fecha de consulta: 23 de junio de 20I7).

Documento i8. "Viaje apostólico del Papa Francisco a Cuba y Estados Unidos de América. Encuentro con los obispos invitados al Encuentro Mundial de las Familias. Seminario de San Carlos Borromeo. Filadelfia. Domingo 27 de septiembre de 2015", Librería Editrice Vaticana. En http://w2.vatican.va/content/francesco/es/speeches/2015/september/documents/papafrancesco_20150927_usa-vescovi-festa-famiglie.html (Fecha de consulta: 23 de junio de 2017). México 2016.

Documento r9. "Viaje apostólico del Papa Francisco a México. Encuentro con las autoridades, la sociedad civil y el cuerpo diplomático. Palacio Nacional. Ciudad de México. Sábado iz de febrero de 20i6", Librería Editrice Vaticana. En http://w2.vatican.va/content/francesco/es/speeches/20I6/february/documents/papafrancesco_20I602I3_messico-autorita.html (Fecha de consulta: 20 de junio de 20I7).

Documento 20. "Viaje apostólico del Papa Francisco a México. Encuentro con los obispos. Catedral Metropolitana, Ciudad de México. Sábado iz de febrero de 2or6", Librería Editrice Vaticana.

En http://w2.vatican.va/content/francesco/es/speeches/20I6/february/documents/papafrancesco_20I60213_messico-vescovi.html (Fecha de consulta: 23 de junio de 20I7).

Documento 21. "Viaje apostólico del Papa Francisco a México. Santa Misa con las comunidades indígenas de Chiapas. Lunes 15 de febrero de 2016", Librería Editrice Vaticana. En http://w2.vatican.va/content/francesco/es/homilies/20i6/documents/papafrancesco_20I602I5_omelia-messico-chiapas.html (Fecha de consulta: 23 de junio de 2017).

Documento 22. "Viaje apostólico del Papa Francisco a México. Encuentro con las familias. Tuxtla Gutiérrez, Chiapas. Lunes I5 de febrero de 2016", Librería Editrice Vaticana. En http://w2.vatican.va/content/francesco/es/speeches/20I6/february/documents/papafrancesco_20I60215_messico-famiglie.html(Fecha de consulta: 23 de junio de 20I7). 
Documento 23. "Viaje apostólico del Papa Francisco a México. Encuentro con los jóvenes en el estadio "José María Morelos y Pavón". Morelia, Michoacán. Martes i6 de febrero de 20i6", Librería Editrice Vaticana. En http://w2.vatican.va/content/francesco/es/speeches/20I6/february/documents/papafrancesco_20160216_messico-giovani.html (Fecha de consulta: 23 de junio de 2017).

Documento 24. "Viaje apostólico del Papa Francisco a México. Visita al Centro de Readaptación Social (cereso 3) de Ciudad Juárez. Miércoles i7 de febrero de 20i6", Librería Editrice Vaticana.

En http://w2.vatican.va/content/francesco/es/speeches/20I6/february/documents/papafrancesco_201602I7_messico-detenuti.html (Fecha de consulta: 23 de junio de 2017).

Documento 25. "Viaje apostólico del Papa Francisco a México. Santa Misa. Homilia. Área de la Feria de Ciudad Juárez. Miércoles i7 de febrero de 20i6", Librería Editrice Vaticana. En http://w2.vatican.va/content/francesco/es/homilies/2016/documents/papa-

francesco_20I60217_omelia-messico-ciudad-jaurez.html (Fecha de consulta: 23 de junio de 20I7).

Chile 2018.

Documento 26. "Viaje apostólico de su santidad Francisco a Chile y Perú. Conferencia de prensa del Santo Padre durante el vuelo de regreso a Roma. Domingo 2i de enero de 20i8", Librería Editrice Vaticana. En http://w2.vatican.va/content/francesco/es/events/event.dir.html/content/vaticanevents/e s/20I8/I/2I/voloritorno-cile-peru.html (Fecha de consulta: 8 de febrero de 20I8). 


\section{Bibliografía}

AGAMBEN, Giorgio. El misterio del mal. Benedicto XVI y el fin de los tiempos. Argentina: Adriana Hidalgo Editora, 20r3.

ALTHUSSER, Louis. La filosofía como arma de la revolución. Buenos Aires: Pasado y Presente, 1984 .

BADIOU, Alain. San Pablo. La fundación del universalismo. Madrid: Anthropos, I999.

BARTHES, Roland. Análisis estructural del relato. Buenos Aires: Tiempo Contemporáneo, I972. La aventura semiológica. Barcelona: Paidós, I982.

Fragmentos de un discurso amoroso. México: Siglo XXI, 2013.

BERGER, Peter L. y Thomas LUCKMANN. La construcción social de la realidad. Buenos Aires: Amorrortu, I99I.

BOFF, Leonardo. Iglesia: carisma y poder. Ensayos de eclesiología militante. Santander: Sal Terrae, 1992.

ECO, Umberto. Obra abierta. Madrid: Planeta Agostini, 1992.

FERNÁNDEZ VEGA, José. Francisco y Benedicto, El Vaticano ante la crisis global. Buenos Aires: Fondo de Cultura Económica, 2016.

FONTCUBERTA, Joan. La furia de las imágenes. Notas sobre la postfotografía. Barcelona: Galaxia Gutemberg, 2016.

FRANCISCO. La alegría del Evangelio. Evangelii Gaudium. Exhortación apostólica del Santo Padre Francisco. México: Ediciones Paulinas, 2013.

GUARDINI, Giordano. El poder. Un intento de orientación. Madrid: Guadarrama, I963.

HABERMAS, Jürgen. “Observaciones sobre el concepto de acción comunicativa (1982)". En Teoría de la acción comunicativa: complementos y estudios previos. Jürgen Habermas. Madrid: Cátedra, I989.

IVEREIGH, Austen. El gran reformador. Francisco, retrato de un Papa radical. Barcelona: Grupo Z, 2016.

KÜNG, Hans. La Iglesia. Barcelona: Herder, I984.

MARDONES, José María. La vida del símbolo. Madrid: Sal Terrae, 2005. 
PAOLI, Arturo. Diálogo de la liberación. Buenos Aires: Carlos Lohlé, I970.

PEREA, Joaquín, José I. GONZÁLEZ, Andrés TORRES y Javier VITORIA. Clamor contra el gueto. Textos sobre la crisis de la Iglesia. Madrid: Trotta, zor2.

PERELMAN, Chaïm y Lucie OLBRECHTS-TYTECA. Tratado de la argumentación. La nueva retórica. Madrid: Gredos, 1989.

POLITI, Marco. Francisco entre los lobos. El secreto de una revolución. Buenos Aires: Fondo de Cultura Económica, 2015.

RAMÍREZ, Ma. del Sagrario. Métodos de educación de adultos. Madrid: Marsiega, I972.

REAL ACADEMIA DE LA LENGUA, ASOCIACIÓN DE ACADEMIAS DE LA LENGUA ESPAÑOLA, Nueva gramática de la lengua española. Morfología sintaxis I (Madrid: Espasa libros, 2009), I-I2C.

SARANYANA, Josep-Ignasi, dir., Teología en América Latina. Vol. III. El siglo de las teologías latinoamericanistas (I899-200I). Cap. III "La acción social y cultural de los católicos hasta el Vaticano II". Madrid: Iberoamericana, Vervuert, 2002.

SCHUTZ, Alfred. El problema de la realidad social. Buenos Aires: Amorrortu, I995.

VIDAL, Senén, ed. Nuevo testamento. Cantabria: Sal Terrae, 2015.

WEBER, Max. La ética protestante y el espíritu del capitalismo. México: Fondo de Cultura Económica, 2003.

. Economía y sociedad. Nueva edición revisada, comentada y anotada por Francisco Gil Villegas. México: Fondo de Cultura Económica, 2014.

WIGODER, Geoffrey, editor general. Diccionario ilustrado de la Biblia. México: Reader's Digest, I995.

ZIZEK, Slavoj. Acontecimiento. México: Sexto piso, 2014.

Relaciones Estudios de Historia y Sociedad, vol. XL, núm 157, 2019 


\section{Notas}

I Debido a la larga extensión de los documentos de la Librería Editrice Vaticana consultados en su página web indicaremos numéricamente, de aquí en adelante, el documento citado cuya referencia completa se especificará en la sección de fuentes al final del artículo. Librería Editrice Vaticana, documento i: LEV, I.

2 Consúltese "Antonio Spadaro SJ entrevista al Papa Francisco", Razón y Fe (2017), en http://razonyfe.org/entrevista-al-papa (Fecha de consulta: 2I de junio de 20I7).

3 Entre el 8 de diciembre de 2015 y el 20 de diciembre de 20r6, la Iglesia celebró el año de Jubileo de la Misericordia, para conmemorar el $50^{\circ}$ aniversario de la clausura del Concilio Vaticano II. Este Jubileo fue ordenado por Francisco como un año santo extraordinario que reafirma la presencia de la Iglesia en el mundo y el lugar central que en ella ocupa la Divina Misericordia. Como signo visible de esta celebración se abrió la Puerta Santa de la Archibasílica de San Juan de Letrán, Catedral de Roma, y las equiparables en cada una de las catedrales del mundo católico.

${ }_{4}$ Consúltese https://www.charterforcompassion.org/

5 Véase sobre el planteamiento de este problema Max Weber, "Introducción general a los Ensayos sobre sociología de la religión (I220)", en La ética protestante y el espíritu del capitalismo_(México: Fondo de Cultura Económica, 2003)

$6 \mathrm{~V}$ Conferencia General del Episcopado Latinoamericano y el Caribe, Aparecida. Documento conclusivo (México: Ediciones CEM, 2007).

$7 \mathrm{Al}$ respecto, estamos en sintonía con las obras de Alfred Schutz, El problema de la realidad social (Buenos Aires: Amorrortu, I995); y Peter L. Berger y Thomas Luckmann, La construcción social de la realidad (Buenos Aires: Amorrortu, I9gI).

8 Jürgen Habermas, "Observaciones sobre el concepto de acción comunicativa (1982), en Teoría de la acción comunicativa: complementos y estudios previos (Madrid: Cátedra, I989), 48I.

9 Francisco, La alegría del Evangelio. Evangelii Gaudium. Exhortación apostólica del Santo Padre Francisco (México: Ediciones Paulinas, 20I3). Véase el capítulo II, sección III "La preparación de la predicación", II7-I28.

Io Roland Barthes, La aventura semiológica (Barcelona: Paidós, 1982) Incluyo como obras de consulta que influyeron en el diseño metodológico a Chaïm Perelman y Lucie OlbrechtsTyteca, Tratado de la argumentación. La nueva retórica(Madrid: Gredos, I989); y Umberto Eco, Obra abierta (Madrid: Planeta Agostini, rgg2).

II Ma. del Sagrario Ramírez, Métodos de educación de adultos II (Madrid: Marsiega, 1972) 
I3 Louis Althusser, La filosofía como arma de la revolución (Buenos Aires: Pasado y Presente, I984)

I4 Oposición althusseriana-lacaniana expuesta por Slavoj Zizek, en El frágil absoluto. ¿Por qué merece la pena luchar por el legado cristiano? (Valencia: Pre-Textos, 2009), p. I65.

I5 En el contexto del Concilio Vaticano II, por la apertura de la Iglesia al mundo, los viajes apostólicos de carisma pastoral los inició Paulo VI. Se sabe que san Juan Pablo II en sus veintiséis años de papado realizó alrededor de I3I viajes apostólicos fuera de Italia, entre los cuales 42 fueron a países de Centroamérica y de Latinoamérica, destacando de ellos México por las seis visitas que realizó aquí. Benedicto XVI tuvo veintiséis viajes apostólicos, la mayoría en países europeos y solamente cuatro en el continente americano. Hasta junio de 20I7, Francisco ha realizado veintidós de estos viajes, de los cuales siete han sido al continente americano.

I6 LEV, I9.

I7 José María Mardones, La vida del símbolo (Madrid: Sal Terrae, 2005), Io.

I8 Geoffrey Wigoder, ed., Diccionario ilustrado de la Biblia (México: Reader's Digest, I995), 720.

I9 LEV, 7 .

20 "Los exhorto a conservar la comunión y la unidad entre ustedes (...) Si tienen que pelearse, peléense; si tienen que decirse cosas, se las digan, pero como hombres, en la cara, y como hombres de Dios que después van a rezar juntos, a discernir juntos. Y si se pasaron de la raya, a pedirse perdón, pero mantengan la unidad del cuerpo episcopal. (...) No se necesita "príncipes", sino una comunidad de testigos del Señor". LEV, 20.

2I LEV, 7.

22 Véanse Marco Politi, Francisco entre los lobos. El secreto de una revolución (Buenos Aires: Fondo de Cultura Económica, 2015); y José Fernández Vega,Francisco y Benedicto. El Vaticano ante la crisis global (Buenos Aires: Fondo de Cultura Económica, 2016).

23 Una nota interesante de Max Weber sobre el carisma es la que rechaza explicarlo como representación política; el carisma es lo que es o, según la propia expresión de Weber, la "epifanía de sí misma”. Max Weber, Economía y sociedad. (México: Fondo de Cultura Económica, 20I4), I07. Es sugerente esta ruta que traza Weber para dialogar con el argumento de Austen Ivereigh, cuya biografía de Mario Jorge Bergoglio sustenta que los pilares del carisma de Francisco son la forja de experiencias de vida y el discernimiento generado por una constante disciplina del sacerdote jesuita fiel a su fe. Por decirlo con otras palabras, Francisco no habla de la misericordia, sino que está en la misericordia porque ese ha sido uno de los derroteros de su vocación sacerdotal. Austen Ivereigh, El gran reformador. Francisco, retrato de un Papa radical (Barcelona: Grupo Z, 2016). 
24 Leonardo Boff, Iglesia: carisma y poder. Ensayos de eclesiología militante (Santander: Sal Terrae, I992), I4.

25 El teólogo Hans Küng se pregunta si acaso “¿no fue desplazado muy pronto, ya en el Nuevo Testamento, el primigenio mensaje de Jesús acerca del Reino de Dios en la Iglesia y por la Iglesia? También aquí resultan instructivos e inquietantes los resultados del análisis estadístico de las palabras: En el Evangelio de Lucas el 'Reino de Dios' ocurre, en números redondos, cuarenta veces; en todo el libro de los Hechos sólo siete veces; en los extensos discursos misionales de los Hechos, nunca en absoluto". Hans Küng, La Iglesia (Barcelona: Herder, Ig84), Iog-IIO.

26 Leonardo Boff, Iglesia: carisma y poder.

27 Leonardo Boff, Iglesia: carisma y poder, 15 .

28 Es necesario despejar la tentación de equiparar con la metodología de investigación de las ciencias sociales lo que en el medio eclesiástico es un método de lectura e interpretación de "lo real" en su tríada ver-juzgar-actuar. Francisco reivindica este método, cuyo linaje remite a los grupos de la acción social católica en la primera mitad del siglo XX, precisando que no es través de la lógica del intelecto que los hechos se diagnostican para orientar las acciones pastorales sino de una hermenéutica de la fe que combina: el conocimiento de la palabra de Dios vertida en el Evangelio con el discernimiento, forjado en la oración, la contemplación y la atenta escucha de lo que Dios dice a través de su pueblo.

29 Véase Josep-Ignasi Saranyana, dir., Teología en América Latina, vol. III. El siglo de las teologías latinoamericanistas (I899-200I), cap. III "La acción social y cultural de los católicos hasta el Vaticano II" (Madrid: Iberoamericana, Vervuert, 2002).

$30 \mathrm{LEV}, 2 \mathrm{I}$.

3I Véase Ivereigh, El gran reformador, capítulos 2 y 3.

32 Referimos las encíclicas Mater et Magistra. La doctrina social de la Iglesia (I96I) de Juan XXIII y Populorum Progressio (1967) de Paulo VI cuya denuncia de las condiciones de pobreza en las economías periféricas es considerada precedente de la II CELAM celebrada en Medellín, Colombia (1968).

33 Entrevista a Lucio Gera al cumplir cincuenta años de sacerdocio, citado en Saranyana, Teología en América Latina, 331.

34 Consúltese "Gracias a Bergoglio el documento de Aparecida más que un texto es una realidad", entrevista con Susana Nuín, directora ejecutiva de comunicación del CELAM, Zenit, el mundo visto desde Roma (25 de junio de 2013), en https://es.zenit.org/articles/gracias-abergoglio-el-documento-de-aparecida-mas-que-un-texto-es-una-realidad/25/ Fecha de consulta: 23 de mayo de 2017 ). 
35 Arturo Paoli, Diálogo de la liberación (Buenos Aires: Carlos Lohlé, ig7o), 51 y 53. Francisco conoció a Arturo Paoli en Argentina cuando fue provincial de los jesuitas. Paoli perteneció a la congregación de los Hermanitos de Jesús y fue sacerdote activo en el Movimiento de los Sacerdotes del Tercer Mundo; a la edad de ior años se encontró con Francisco en el Vaticano.

$36 \mathrm{LEV}, \mathrm{I} 5$.

37 Joan Corominas, Breve diccionario etimológico de la lengua castellana (Madrid: Gredos, I998), 397 .

38 Consúltese "Rueda de prensa con el recién nombrado Papa Francisco", ACI Prensa (i6 de marzo de 2013), en https://www.aciprensa.com/noticias/papa-francisco-explica-por-que-eligioeste-nombre-77323/ (Fecha de consulta: 20 de junio de 20I7).

39 Roland Barthes, "Introducción al análisis estructural de los relatos", en Análisis estructural del relato, varios autores (Buenos Aires: Tiempo Contemporáneo, 1972); y Roland Barthes, Fragmentos de un discurso amoroso (México: Siglo XXI, 20I3).

40 LEV, 2.

4I LEV, 2.

$42 \mathrm{LEV}, 8$.

$43 \mathrm{LEV}, 7$.

$44 \mathrm{LEV}, \mathrm{I} 3$.

$45 \mathrm{LEV}$, I9.

$46 \mathrm{LEV}, 5$.

$47 \mathrm{LEV}, 5$.

$48 \mathrm{LEV}, 6$.

$49 \mathrm{LEV}, 6$.

50 LEV, 20.

5I LEV, 2.

$52 \mathrm{LEV}, 22$.

$53 \mathrm{LEV}, 24$.

Relaciones Estudios de Historia y Sociedad, vol. XL, núm I57, 2019 
$54 \mathrm{LEV}, 24$.

$55 \mathrm{LEV}, 3$.

$56 \mathrm{LEV}, 3$.

$57 \mathrm{LEV}$, I3.

$58 \mathrm{LEV}, 20$.

$59 \mathrm{LEV}, 20$.

6o LEV, I6.

6I LEV, 20.

62 LEV, 2I.

$63 \mathrm{LEV}, \mathrm{I} 4$.

$\mathbf{6}_{4} \mathrm{LEV}, 5$.

${ }_{5} \mathrm{LEV}, 5$.

$66 \mathrm{LEV}, \mathrm{I} 7$.

$67 \mathrm{LEV}, \mathrm{I} 8$.

$68 \mathrm{LEV}$, I8.

$69 \mathrm{LEV}, \mathrm{I} 7$.

7o Consúltese "Papa realiza polémica defensa de obispo Barros: 'Osorno sufre por tonta", BioBioChile, en http://www.biobiochile.cl/noticias/2015/Io/o2/papa-realiza-polemicadefensa-de-obispo-barros-osorno-sufre-por-tonta.shtml (Fecha de consulta: io de febrero de 2018).

7I Fuente de seguimiento en la prensa del viaje apostólico en Chile: Bernardo Barranco, especial para La Jornada (martes i6, miércoles i7 y jueves i8 de enero de 2018).

72 Juan Andrés Murillo, Juan Carlos Cruz y James Hamilton, víctimas de Karadima, leyeron una declaración donde exponen su situación respecto a la defensa del papa al obispo de Osorno. Consúltese en https://www.youtube.com/watch?v=uaTqShRcHBA (Fecha de consulta: II de febrero de 2018). 
$73 \mathrm{LEV}, 26$.

74 Slavoj Zizek, Acontecimiento (México: Sexto Piso, 20I4), 23.

75 Joan Fontcuberta, La furia de las imágenes. Notas sobre la postfotografía (Barcelona: Galaxia Gutemberg, 2016), 7 .

76 Giorgio Agamben, El misterio del mal. Benedicto XVI y el fin de los tiempos_(Argentina: Adriana Hidalgo Editora, 2013).

77 Sobre el tema de las luchas internas en la Iglesia para obstaculizar y dar marcha atrás las constituciones y decretos del Concilio Vaticano II, véase \oaquín Perea et al., eds., Clamor contra el gueto. Textos sobre la crisis de la Iglesia (Madrid: Trotta, 20I2).

78 Senén Vidal, ed., Nuevo testamento (Santander: Sal Terrae, 2015), 292.

\section{Miguel J. Hernández Madrid}

Doctor en Ciencias Sociales con especialidad en Antropología Social. Ciesas-Occidente. 3. Adscripción institucional: Profesor Investigador titular "C", en el Centro de Estudios Rurales de El Colegio de Michoacán. Líneas de investigación: a) Religión, sociedad y migración en el occidente de México; b) Sufrimiento social y hospitalidad trashumante en la era de las expulsiones. Últimas publicaciones: Documentos de pastoral cívica y social de la Iglesia católica en la diócesis de Zamora, Michoacán 1930-1975. Zamora: El Colegio de Michoacán, 20I4; "El proceso de convertirse en creyentes. Identidades de familias testigos de Jehová en un contexto de migración transnacional". En El impacto de la migración a Estados Unidos en comunidades de origen en México. A través de Relaciones. Estudios de Historia y Sociedad, comp. Rafael Alarcón Acosta. Zamora: El Colegio de Michoacán, 20I7, 223-258; "La experiencia social de la responsabilidad moral por el Otro en los circuitos trashumantes de la pastoral migrante México-Estados Unidos". Metapolítica, año I8(85) (abril-junio 2014): 65-71 